DOI https://doi.org/10.18551/rjoas.2017-01.13

\title{
INCOME DISPARITY AMONG HIGH-RISK JOB WORKERS OF ACROSS-CITIES ACROSS-PROVINCES AUTOBUS DRIVERS IN SOUTH SUMATERA, INDONESIA
}

\author{
Paisal, Tarmizi Nurlina, Syamsurijal A.K., Soebyakto Bambang Bemby \\ Faculty of Economics, University of Sriwijaya, Indonesia \\ *E-mail: paisal.conk@gmail.com
}

\begin{abstract}
This study analysed the income disparity among the high-risk job of inter-city inter-province bus drivers in South Sumatera. The high number of road accident showed that inter-city inter-province autobus drivers' job is a high-risk job. High-risk jobs should be compensated with high salary. In this study, primary and secondary data were analyzed. Saturated sampling technique was used involving 71 intra-Sumatera bus drivers and 125 SumateraJava bus drivers to participate in this study. The result of analysis of Blinder-Oaxaca decomposition that there is income disparity among the bus drivers which is caused by the three endowments that were facilities, environment, and compensation. There were two factors that divides the income disparity into two categories; value of factors causing the disparity at 38.993 and unexplainable factors at 2.728 . The total of the income disparity was 41.159.
\end{abstract}

\section{KEY WORDS}

Income disparity, across-cities across-provinces (AKAP), Blinder-Oaxaca.

Risky job is a relatively least wanted jobs since it is less interesting and its characteristics cause income disparities. Safe jobs are jobs that provide high social status, flexible work durations, indoor, and is located in comfortable and safe environment which is less risky. On the other hand, risky jobs are the ones with shabby work environment, monotonous tasks, low social status, and located in unsafe places with high risks (Nurlina, 2012).

Adam Smith stated that risky job workers should be compensated with higher salary than others. The high salary is able to increase workers' interests which also causes income disparities at the same time.

There are some jobs that are categorized as risky jobs such as mining workers, construction workers, chemical factory workers, fire fighters, truck drivers, public transportation drivers, and so on. Across-cities across-provinces bus drivers (AKAP) are also workers of risky jobs.

This study aimed at understanding the influence of human capital, job risks, and the compensation system of workers' income as well as the income disparities among the intercity inter-province autobus drivers of Java-Sumatera route.

\section{LITERATURE REVIEW}

The Theory of Hedonic Commission. Higher salary should be given as the compensation to the unfavourable job workers. Besides being compensated for the unfavourable work conditions that they are working in, they also need to be compensated for their risky jobs that may trigger fatal risks, injuries and illness. There are some jobs that do not require workers to have high skills but the jobs are unsafe and risky. Companies pay higher salary for workers working in this unfavourable condition.

Compensation in the form of income disparity is an impotant social necessity which provides incentives for workers who are willing to do the unsafe jobs. Secondly, it is a reward for them who are doing unsafe jobs compared to other workers of safe jobs.

One of theoretical approaches that can be used to analyze factors that cause income disparity in marketplace is the hedonic theory proposed by Jeremy Bentham. This theory was 
the result of hedonic thought that hypothesized that a person will act in a certain way to maximize happiness (from the income) and to avoid risks such as the risks from working in unsafe environment (Mc Connel, et al, 1999: 226).

Hedonism refers to the behavior of a person to work for happiness. In this case, workers are making the most of their utility to achieve happiness. The level of income reflects the risk level of a job. If a job has high injury risk, then the income received by the workers is higher. The high salary is given as the compensation of the high risks that they have to bear and to maintain workers' constant utility in doing the job. Thus, there has to be compensation for every risk in a job in order to be able to maintain certain level of workers' utility.

Income disparity is implemented as an attempt to interest workers to work in such unfavourable conditions with high risks. In another words, the higher the risk of a job, the higher the compensation should be paid by a company (Kaufman and Hotchkiss, 2005: 397).

It is assumed that all workers have already given complete information regarding to risks of the job and they have understood that they are working on unsafe and risky jobs. This is quite important since there are still more undetected risks of the job in the future. From the explanation, it can be understood that workers' utility does not only rely on the level of income, but it also is determined by the risks of the job. Thus, the formula for utility is Utility $=f(w$. risks).

It is assumed that when a worker choses job with higher salary, then the marginal utility is positive. On the other way around, jobs with high risks creates negative marginal utility. However, when a worker enjoys working the risky job, then their marginal utility is positive. The marginal utility of the job risk is the change of the utility as the impact of the accident probability within an assumed constant income. Marginal utility of income is the change of utility level as the result of the increased income with assumed constant risks.

\section{RESEARCH METHODS}

Types and Data Source. Primary and secondary data were collected and analyzed in this study. The primary data were collected from the direct interviews with the drivers using inteview guides and questionnaire distribution. Whislt, the secondary data were obtained from the data of police, $K N K T$, and other parties and other documents related to the acrosscities across-provinces bus drivers whose routes have been registered to the data of the Ministry of Transportaion, Communication and Informatics, South Sumatera Province.

Population and Sample. The population of this study are 196 inter-city inter-province bus drivers who worked for inter-city inter-province bus companies. The sampling was done using saturated sampling technique which involved all the population to be taken as the sample which was divided into two categories; 71 drivers of Sumatera route and 125 drivers of Java route.

Data Collection Technique. The data of this study were collected through interviews and from the result of questionnaire distribution. Interviews were conducted using interview guide that consists of questions related to the intended data in this study to achieve the research objectives. Questionnaires that consisted of a series of questions were distributed to all of the inter-city inter-province bus drivers.

Operational Definition and Variable Measurement. Definition of operational variables is the specific definition of the measurement criteria or measurement technique that is created by determining the empirical indicators of a concept (Simamora, 2004). In this study, variables that were measured and analyzed are:

a. Drivers' income $(Y)$ is any financial reward received by drivers for their work or service to the company within a month. The ratio scale is used to measure this variable.

b. Human capital workers are explained by driving skill and driving experience of the drivers. Driving skill $\left(X_{1}\right)$ is the skill of a driver in controlling the ordinal skill measurement of the driver. $\left(X_{2}\right)$ is the duration of a driver working as inter-city inter-province bus driver. Nominal scale is used to measure this variable.

c. Job risk refers to the threats to the health and safety of the workers in performing the job as bus drivers. In this study, the concept of job risk is explained by several variables: 
- Work durations $\left(X_{3}\right)$ is the duration of a driver in driving a bus started from a starting point to the destined point. Nominal scale is used to measure this variable.

- The distance $\left(\mathrm{X}_{4}\right)$ is the length of the distance that should be travelled by the driver from the starting point to the finish point. Nominal scale is used to measure this variable.

- Quality of the quality of the vehicle $\left(X_{5}\right)$ is the condition of the bus that is used to carry passengers from the starting point to the destination. Ordinal scale is used to measure this variable.

- Environment $\left(X_{6}\right)$ is the place or surrounding where the drivers do the jobs or the route that should be taken including the condition of the road, climate or weather, and the safety or threats that might be threatening for the drivers in doing their job. Ordinal scale is used to measure this variable.

d. Compensation system is the real form of compensation that is received by the drivers for their work that is explained by this variable.

- Compensation $\left(X_{7}\right)$ is the way a company pays the inter-city inter-province bus drivers' service done for the company. Ordinal scale is used to measure this variable.

e. $(A K A P)$ Inter-city inter-province transportation is land transportations that carry passengers across cities and across provinces.

The measurement of the value of the variables on the questionnaires items in this study was done using Likert scale. Likert scale was used to measure the response of the subjects on the four points that ranges from 1 to 4 (1. Totally disagree, 2. Disagree, 3. Agree, 4. Totally agree).

Data Analysis Technique. To analyze the data of this study, qualitative and quantitative approaches were administered. Cross-tabulation, double linear regression using SPSS 19 and Oaxaca and Blinder decomposition were used to analyze the data. In order to find out the variables that influence the income of the inter-city inter-province bus drivers in Sumatera and Java, hypothesis testing was administered to hypothesis 1 and hypothesis 2 using these following equations:

$$
\begin{aligned}
& \mathrm{Y}^{s}=a_{0}^{S}+a_{1}^{S} \mathrm{X}_{1}+a_{2}^{S} \mathrm{X}_{2}+a_{3}^{S} \mathrm{X}_{3}+a_{4}^{S} \mathrm{X}_{4}+a_{5}^{S} \mathrm{X}_{5}+a_{6}^{S} \mathrm{X}_{6}+a_{7}^{S} \mathrm{X}_{7}+\mathrm{e}^{\mathrm{s}} \\
& \mathrm{Y}^{\mathrm{j}}=a_{0}^{j}+a_{1}^{j} \mathrm{X}_{1}+a_{2}^{j} \mathrm{X}_{2}+a_{3}^{j} \mathrm{X}_{3}+a_{4}^{j} \mathrm{X}_{4}+a_{5}^{j} \mathrm{X}_{5}+a_{6}^{j} \mathrm{X}_{6}+a_{7}^{j} \mathrm{X}_{7}+\mathrm{e}^{\mathrm{j}}
\end{aligned}
$$

Notes:

$$
\begin{aligned}
& Y^{s}=\text { Drivers' income of Sumatera route; } \\
& Y^{j}=\text { Drivers' income of Java route; } \\
& a_{0}^{S}, a_{0}^{j}=\text { Constanta; } \\
& a_{i}^{S}, a_{i}^{j}=\text { Regression coefficient; } \\
& X_{1}=\text { Skill; } \\
& X_{2}=\text { Experience; } \\
& X_{3}=\text { Work duration; } \\
& X_{4}=\text { Distance; } \\
& X_{5}=\text { Quality of the vehicle; } \\
& X_{6}=\text { Environment; } \\
& X_{7}=\text { Compensation; } \\
& e^{S}=\text { Standard of error. }
\end{aligned}
$$

To analyze the income disparity, Blinder-Oaxaca decompoisiton (1973) was used. Theoretically, Blinder-Oaxaca decomposition is divided into two types; disparity that is caused by variety of endowment and disparity which is caused by unexplainable factors. The drivers' income disparity of Sumatera route and Java route is formulated using these following equations:

$$
\begin{aligned}
& Y^{\varsigma}=a_{0}^{S}+\sum_{i}^{S} a_{i}^{S} X_{i}^{S}+\epsilon^{S} \\
& Y^{\mathrm{j}}=a_{0}^{J}+\sum_{i}^{J} a_{i}^{J} X_{i}^{J}+\epsilon^{J}
\end{aligned}
$$


in which $\mathrm{S}$ is the drivers' income of Sumatera route and $\mathrm{J}$ is the drivers' income of Java route. Blinder (1973) showed that the average gap of the income logarithm can be decomposed:

$$
\bar{Y}^{s}-\bar{Y}^{\mathrm{j}}=\left[a_{0}^{S}-a_{0}^{J}\right] \sum_{i}^{n} a_{i}^{S}\left[\bar{X}_{\mathrm{i}}^{\mathrm{s}}-\bar{X}_{\mathrm{i}}^{\mathrm{j}}\right]+\sum_{i}^{n} \bar{X}_{\mathrm{i}}^{\mathrm{j}}\left(a_{0}^{S}-a_{0}^{J}\right)
$$

The line (bar) above the variable shows the average gap of income logarithm that can be decomposed as follows:

$$
\text { Raw differential }(\mathrm{R})=a_{0}^{S}+\sum_{i}^{n} a_{i}^{S} \bar{X}_{\mathrm{i}}^{\mathrm{s}}-\left(a_{0}^{J}+\sum_{i}^{n} a_{i}^{J} X_{i}^{J}\right)=\mathrm{E}+\mathrm{C}+\mathrm{U}=\bar{Y}^{\mathrm{s}}-\bar{Y}^{\mathrm{j}}
$$

E differential portion caused by endowment differences:

$$
\mathrm{E}=a_{0}^{S}\left(\bar{X}^{\mathrm{s}}{ }_{i}-\bar{X}_{\mathrm{i}}^{\mathrm{j}}\right)
$$

$\mathrm{C}=$ differential portion caused by different coefficient:

$$
\mathrm{C}=\bar{X}_{\mathrm{i}}^{\mathrm{j}}\left(a_{0}^{S}-a_{0}^{J}\right)
$$

U Unexplainable differential portion:

$$
\begin{aligned}
& \mathrm{U}=\left(a_{0}^{S}-a_{0}^{J}\right) \\
& \mathrm{D}=\mathrm{C}+\mathrm{U}
\end{aligned}
$$

Differential percentage $=D / R$

where: $Y^{s}=$ Drivers' income of Sumatera route; $Y^{j}=$ Drivers' income of Java route.

\section{DATA ANALYSIS}

Instrument Testing. The data of this study were in the form of primary and secondary data. In social research context, the validity and the reliability of the data relied on the instrument and measurement system that were used in the study. If the instruments that are used in a study was invalid or unreliable, the result of the study would not be able to reflect the truth in the field. Based on the standard procedure of constructing research instrument, before being used as the instrument in the research, classic assumption test has been administered to the instrument. In this study, there were three tests administered to check the validity of the instruments that were normal test, heterogeneity test and multi co-linearity test.

The Effect of Human Capital, Job Risk, and Compensation System toward the Income of Inter-Cities Inter Provinces Bus Drivers for Sumatera Route. Working as inter-cities inter provinces bus driver deals a lot with passengers' comfort, security and safety. This research spots on human capital as the person who drives the across-cities across-provinces bus. The risks that can be triggered by a job determine the riskiness level of a job. The compensation system is the form of compensation given to the across-cities across-provinces bus drivers which is drivers' income. The following table shows the model of human capital, job risk and compensation system to the across-cities across-provinces bus drivers' income for Sumatera route.

Based on the result of the estimated model, it can be seen that the standard of coefficient (Beta) work duration variable $(-0.596)$ had a high negative value which means the variable of work duration had negatively bigger or negative dominant influence to the drivers' income. It implies that the longer a driver driving the bus, the higher the salary that should be given. Yet, the result of the estimated model shows that the longer the driving duration, the 
lesser the income earned by the driver. In this case, compensation is given based on the salary system which adds up the incentive which was called Uang Dinas Jalan of around $10 \%-15 \%$ of the total sold ticket for a certain route. If the distance is short but it requires longer time to travel, then it would not be beneficial seen from the time efficiency and other operational expenses. On the other way around, then the distance is far but it can be reached within short time, it gives some benefits in the form of extra income for the drivers.

Table 1 - Estimated Model of Human Capital, Job Risk, and Compensation System toward the Income of Inter-Cities Inter Provinces Bus Drivers for Sumatera Route

\begin{tabular}{|c|c|c|c|c|c|}
\hline Variable & $\mathrm{B}$ & SE & Beta & $\mathrm{T}$ & Sig \\
\hline C & $-0,912$ & 0,647 & - & $-1,409$ & 0,164 \\
\hline Skills & 0,027 & 0,058 & 0,056 & 0,476 & 0,636 \\
\hline Experience & 0,411 & 0,184 & 0,291 & 2,230 & 0,029 \\
\hline Work duration & $-1,560$ & 0,388 & $-0,586$ & $-4,019$ & 0,000 \\
\hline Distance & 0,001 & 0,027 & 0,006 & 0,055 & 0,957 \\
\hline Quality of the vehicle & 1,100 & 0,303 & 0,555 & 3,626 & 0,001 \\
\hline Environment & 0,354 & 0,107 & 0,326 & 3,300 & 0,002 \\
\hline Compensation & $-0,202$ & 0,095 & $-0,216$ & $-2,131$ & 0,037 \\
\hline \multicolumn{6}{|l|}{$R=0,771$} \\
\hline \multicolumn{6}{|l|}{$R$ square $=0,594$} \\
\hline \multicolumn{6}{|l|}{ Adj. $\mathrm{R}$ square $=0,549$} \\
\hline \multicolumn{6}{|l|}{ SE Estimation $=0,214$} \\
\hline$F=13,150(0,000)$ & & & & & \\
\hline
\end{tabular}

Dependent variable: Income.

Source: Primary data interpretation (2016).

The result of the estimated model was then transformed into the equations of acrosscities across-provinces bus drivers of Sumatera route as follows:

$$
\begin{gathered}
Y^{s}=a_{0}^{S}+a_{1}^{S} \mathrm{X}_{1}+a_{2}^{S} \mathrm{X}_{2}+a_{3}^{S} \mathrm{X}_{3}+a_{4}^{S} \mathrm{X}_{4}+a_{5}^{S} \mathrm{X}_{5}+a_{6}^{S} \mathrm{X}_{6}+a_{7}^{S} \mathrm{X}_{7}+\mathrm{e}^{s} \\
Y^{s}=-0,912+0,027 \mathrm{X}_{1}+0,411 \mathrm{X}_{2}-1,560 \mathrm{X}_{3}+0,001 \mathrm{X}_{4}+1,100 \mathrm{X}_{5}+0,354 \mathrm{X}_{6}-0,202 \mathrm{X}_{7}
\end{gathered}
$$

From the result of the estimated model, the value $R=0.711$. This coefficient shows the strength of the correlation between the independent variables toward the dependent variables. It shows that there is a strong correlation among the skill, experience, work duration, distance, quality of the vehicle, environment and the compensation altogether toward the variable of income. Meanwhile the $R^{2}$ (R Square) was found at 0.594 or $59.4 \%$. This value shows that skills, experience, work duration, distance, quality of the vehicle, environment and compensation variables simultaneously influence the income at $59.4 \%$ and the other $40.6 \%$ is the contribution of other variables which are not discussed in this study.

$\mathrm{F}$ test was administered to see if the independent variables simultaneously give significant influence to the dependent variable, or to see whether or not the regression model can be used to predict the dependent variable. The skill, experience, work duration, distance, quality of the vehicle, environment and the compensation variables had simultaneous influence toward the income at 13.15. From the result of the analysis $F_{\text {value }}$ is 13.15 (sig 0.000 )

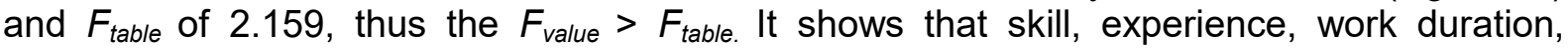
distance, quality of the vehicle, environment and the compensation have simultaneous and significant influence to the drivers' income of Sumatera route.

The result of the estimated model showed $t_{\text {value }}$ of every variable as follows; Skill (0.476), Experience (2.230), Work duration (-4.019), Distance (0.055), Quality of the vehicle (3.625), Environment (3.300) dan Compensation (-2.131).The value of $t_{\text {table }}$ is 1.999, thus the value of $t_{\text {value }}>t_{\text {table }}$ which means that there is partial significant influence of every independent variable toward the income. Therefore, it can be concluded that if skill, work duration, distance and compensation show smaller calue than $t_{\text {table, }}$ it means that partially, each of the skill, work duration, distance, and compensation do not influence the income of across-cities across-provinces bus drivers of Sumatera route. 
The Effect of Human Capital, Job Risk, and Compensation System toward the Income of Inter-Cities Inter Provinces Bus Drivers for Java Route. This following table shows the estimated model of human capital, job risk and compensation system toward across-cities across-provinces bus drivers' income for Java route.

Table 2 - Estimated Model of Human Capital, Job Risk, and Compensation System toward the Income of Inter-Cities Inter Provinces Bus Drivers for Java Route

\begin{tabular}{|c|c|c|c|c|c|}
\hline Variabel & B & SE & Beta & $T$ & Sig \\
\hline $\mathrm{C}$ & 1,816 & 0,991 & - & 1,832 & 0,069 \\
\hline Skills & 0,388 & 0,180 & 0,489 & 2,152 & 0,033 \\
\hline Experience & 0,517 & 0,114 & 0,461 & 4,548 & 0,000 \\
\hline Work duration & $-1,934$ & 1, 967 & $-0,097$ & $-0,983$ & 0,327 \\
\hline Distance & 1,171 & 0,357 & 0,456 & 3,275 & 0,001 \\
\hline Quality of the vehicle & $-0,485$ & 0,197 & $-0,609$ & $-2,466$ & 0,015 \\
\hline Environment & $-0,199$ & 0,108 & $-0,177$ & $-1,846$ & 0,067 \\
\hline Compensation & $-0,236$ & 0,072 & $-0,268$ & $-3,271$ & 0,001 \\
\hline $\begin{array}{l}R=0,720 \\
R \text { square }=0,518 \\
\text { Adj. } R \text { square }=0,489 \\
\text { SE Estimation }=0,309 \\
F=17,959(0,000)\end{array}$ & & & & & \\
\hline
\end{tabular}

Dependent variable: Income.

Source: Primary data interpretation (2016).

The result of the estimated model was then transformed into the equations of acrosscities across-provinces bus drivers of Sumatera route as follow:

$$
\begin{gathered}
\mathrm{Y}^{\mathrm{j}}=a_{0}^{j}+a_{1}^{j} \mathrm{X}_{1}+a_{2}^{j} \mathrm{X}_{2}+a_{3}^{j} \mathrm{X}_{3}+a_{4}^{j} \mathrm{X}_{4}+a_{5}^{j} \mathrm{X}_{5}+a_{6}^{j} \mathrm{X}_{6}+a_{7}^{j} \mathrm{X}_{7}+\mathrm{e}^{\mathrm{j}} \\
\mathrm{Y}^{\mathrm{j}}=1,816+0,388 \mathrm{X}_{1}+0,517 \mathrm{X}_{2}-1,934 \mathrm{X}_{3}+1,171 \mathrm{X}_{4}-0,485 \mathrm{X}_{5}-0,199 \mathrm{X}_{6}-0,236 \mathrm{X}_{7}
\end{gathered}
$$

The result of the estimated model shows that the value of standard coefficient (Beta) of quality of the vehicle variable is -0.609 which has high negative value. It implies that the quality of the quality of the vehicle has bigger negative influence or dominant influence toward the drivers' income. The better the quality of the quality of the vehicle, the higher the income that will be earned by the drivers. In this case, the better the quality of the quality of the vehicle, the lesser the earned income. Good quality of the quality of the vehicle will make it easier for the drivers to drive the bus. Yet, in fact, the goodness of the quality of the vehicle does not bring higher income for drivers. It is caused by the fact that when public bus companies improve the quality of the quality of the vehicle or provide new buses, there will be lesser compensation for the drivers compared to the drivers of old vehicle since driving old vehicle is more difficult than driving the new ones.

The result of the estimated model showed $R=0.720$. It shows that there is a strong correlation between the independent variables altogether toward the dependednt variable (drivers' income). $\mathrm{R}^{2}$ ( $\mathrm{R}$ Square) was found at 0.518 or $51.8 \%$ which implies that the influence of the skill, experience, work duration, distance, quality of the vehicle, environment and compensation altogether influence the drivers' income as much as 51.8, whilst the other $48.2 \%$ is the influence of other variables which are not discussed in this study.

The result of the $F_{\text {value }}$ is 17.959 (sig 0.000 ) and the $F_{\text {table }}$ at 2.089. Thus, $F_{\text {value }}>F_{\text {table }}$ which shows that the independent variables; skills, experience, work duration, distance, quality of the vehicle, environment and compensation have simultaneous and significant influence to drivers' income for Java route.

$T$ test was administered to see if the regression model of the independent variables have partial significant influences toward the dependent variables. Based on the estimated model, the $t_{\text {value }}$ of each variable shows result as follows: Skill (2.152), Experience (4.548), Work duration (-0.983), Distance (3.275), Quality of the Vehicle (-2.466), Environment (1.846) and Compensation (-3.271). The $t_{\text {table }}$ value is 1.980 in which skill, experience, and 
distance have $t_{\text {value }}>t_{\text {table }}$, it means that partially, there was a positive influence among the skill, experience and the distance toward drivers' income. Meanwhile, the work duration, quality of the vehicle, environment and compensation have negative influence toward the income of across-cities across-provinces bus drivers for Java route.

The income disparity of across-cities across-provinces (AKAP) bus drivers of Sumatera and Java routes. This study employed the decomposition method proposed by Blinder and Oaxaca (1973) which theoretically divides income disparity into two types which are the income disparity caused by different endowment and income disparity caused by unexplainable factors. After average disparity analysis of across-cities across-provinces bus drivers' income, the disparity value is found as follows:

Table 3 - Average Income of Across-cities across-provinces Bus Drivers in South Sumatera

\begin{tabular}{cccc}
\hline $\begin{array}{c}\text { Category Differences } \\
(1)\end{array}$ & $\begin{array}{c}\text { Mean } \\
(2)\end{array}$ & $\begin{array}{c}\text { Standard of Deviation } \\
(3)\end{array}$ & $\begin{array}{c}\text { Standard of Error mean } \\
(4)\end{array}$ \\
\hline Ln_Income of Driver_1 & 14.842683 & 0.1504516 & 0.178601 \\
Ln_Income of Driver_2 & 14.656834 & 0.1993984 & 0.178347 \\
Total Differences & 0.185849 & & \\
\hline
\end{tabular}

Source: Primary data interpretation (2016).

1 = Sumatera route.

2 = Java route.

Table 3 explains that the average income of the drivers that was derived from the equation In showed estimated value of 14.842683 for drivers of Sumatera route and 14.656832 for drivers of Java route. Thus, there is a difference on the total income of 0.185849 .

The result of the analysis showed that there was income disparity among the drivers of those two across-cities across-provinces bus routes in South Sumatera. After knowing the existence of the income disparity, the data were then analyzed to see the degree of the disparity that could be seen from the positive or negative signs on the endowment value. Each of endowment difference with positive value (benefits for drivers of Sumatera route) reflected higher endowment level of the drivers of Sumatera route compared to drivers of Java route. The difference of the endowment with negative value (benefits for drivers of Java route) means that the drivers of Java route had lower endowment level compared to the drivers of Sumatera route which minimized the gap of the income disparity.

The result of the analysis on the data related to the income sources of the variables showed that there were three variables with positive endowment influence and four variables with negative influence as presented in Table 4.

Table 4 - Blinder-Oaxaca Decomposition of Across-cities across-provinces Bus Drivers

\begin{tabular}{|c|c|c|c|c|}
\hline \multirow[b]{2}{*}{ No } & \multirow[b]{2}{*}{ Variable } & \multicolumn{2}{|c|}{ Cause of the Disparity } & \multirow[b]{2}{*}{$E+C$} \\
\hline & & Endowment $(E)$ & Coefficient (C) & \\
\hline 1. & Skills & -0.4540 & -7.0549 & -7.5089 \\
\hline 2. & Experience & -0.1337 & -2.2451 & -2.3788 \\
\hline 3. & Work duration & -2.1284 & -1.2794 & -3.4079 \\
\hline 4. & Distance & -0.2112 & -3.2600 & -3.4712 \\
\hline 5. & Quality of the vehicle & 0.3944 & -7.1130 & -6.7185 \\
\hline 6. & Environment & 0.0903 & -7.3686 & -7.2783 \\
\hline \multirow[t]{2}{*}{7.} & Compensation & 0.2770 & -7.9442 & -7.6672 \\
\hline & Sub Total & -2.1656 & -36.2652 & -38.4308 \\
\hline \multicolumn{2}{|c|}{ Unexplained (U) } & -2.728 & & \\
\hline \multirow{2}{*}{\multicolumn{2}{|c|}{$\begin{array}{l}\text { Disparity }(D)=C+U \\
\text { Total Disparity }(R)=E+C+U\end{array}$}} & $-38,993$ & & \\
\hline & & -41.159 & & \\
\hline \multicolumn{2}{|c|}{$\begin{array}{l}\text { Total Disparity }(R)=E+C+U \\
\text { Disparity percentage }(D / R)\end{array}$} & $94,74 \%$ & & \\
\hline
\end{tabular}

Source: Primary data interpretation (2016). 
The result of the measurement using the Blinder-Oaxaca decomposition method showed that the skill variable had negative endowment influence of -0.4540 . It showed that drivers' skill only gave small influence to the income disparity. For the variable of drivers' experience, there was a negative endowment influence of -0.1337 which also showed that the experience gave insignificant influence to income disparity. Work duration variable showed negative endowment value of -2.1284 which also showed that work duration gave small influence to the income disparity. The distance of the travel showed negative endowment influence of -0.2112 which showed that the distance of the travel had insignificant influence to the income disparity. Whereas, the quality of vehicle showed positive endowment influence at 0.3944 which means that the quality of the vehicle influenced the income disparity since the maintenance expenses were covered by the company. The quality of the vehicle should be well maintained to provide passengers with comforts and safety. The environment variable showed positive endowment influence of 0.0903 which means that the environment influenced the income disparity. The difficulty level of the environment determines the income since the higher the risk, the higher the salary that should be received by the drivers. Compensation variable also showed positive endowment influence of 0.2770 which showed that the compensation influenced the income. The form of the compensation should be taken into consideration in determining drivers' salary.

Based on the result of the Blinder-Oaxaca decomposition method, the sub total factors causing the disparity (endowment) showed value of -2.1656 with causal coefficient value of 36.2652 and other unexplainable variables as much as -2.728 . Meanwhile, the income disparity is found at -38.993 . The test also shows the total income disparity as much as 41.159 which means that the percentage of the income disparity among bus drivers of Sumatera route and Java route was $94.74 \%$.

Theoretically, the result of the Blinder-Oaxaca decomposition analysis categorizes the drivers' income into two categories; the first one is the income disparity caused by endowment, and the second one is the income disparity caused by unexplainable variables that are not discussed in this study. Out of the seven variables, there were three variables showing positive endowment influences that are the quality of vehicle, environment, and the compensation. It implies that the bus drivers of Sumatera route have higher endowment compared to those of Java route. As the result, those three variables are able to increase the gap of drivers' income disparity.

Excellent vehicle quality enhances the safety, security and the comfort that will satisfy the passengers on board. The number of passenger of Sumatera route is not as big as the number of passengers of the Java route. Passengers are also quite selective in selecting the bus company or armada, choosing only those that provides good service during the acrosscities across-provinces travel. Environment which is related to the road condition and the nature of Sumatera route is more dangerous because the road is desolated and there are many long winding roads and narrow turns. Due to the condition of the nature and the road, drivers are required to keep themselves alert and drive the bus slowly which make the work duration gets longer. The compensation should be given based commission system, but most of bus companies apply salary system for the compensation. Whilst, the other four variables show negative endowment influence that are drivers' skill, experience, work duration, and distance. It means that the bus drivers of Java route have higher endowment level that minimizes the gap on income disparity between drivers of Sumatera route and drivers of Java route.

\section{CONCLUSION AND SUGGESTIONS}

Based on the result of the data analysis, the work duration is the variable that has stronger negative influence or dominant influence to drivers' income for Sumatera route. Meanwhile, for the Java route, the quality of vehicle appears to be the variable that has stronger negative influence or dominant influence to the across-cities across-provinces bus drivers' income. 
The analysis of Blinder-Oaxaca decomposition theoretically divides the income into two types; the first one is the income disparity caused by different endowment and the second one is the income disparity that is caused by other unexplainable factors or variables that are not being discussed in this study. Out of seven variables, there were three variables that show positive endowment effects that are the quality of the vehicle, environment, and compensation which means that the bus drivers of Sumatera route tend to have higher endowment compared to those of Java route. Thus, those three variables determine the gap of drivers' income disparity.

It is important that company consider the work duration of the drivers since driving the bus is a risky job related to the life and safety of passengers. It is necessary that companies give drivers time to take enough rest in order to maintain their bodies fresh and to be able to concentrate well while driving the bus. The quality of the vehicle should also be enhanced over time since this job offers public service to the passengers. Passengers will choose the best armadas that give them comfort, safety, and security during their long trip to their destination. Thus, excellent quality of bus will guarantee the glibness of the travel in order to reach the destination on time as scheduled. When passengers feel comfortable, safe and secure, there will be more prospective passengers who choose bus as their preferred transportation. Therefore, government as the rule maker and policy maker should always control the public service of this land-transportation sub sector by regularly checking the quality of service given by bus companies.

Moreover, the welfare or prosperity of across-cities across-provinces bus drivers should be taken into account since this job has high-risk level and it deals with the life and safety of the drivers and the passengers as well. The level of riskiness reflects the amount of salary that should be received by the workers. Thus, it is rightful to give bus drivers high income for their work. By giving them their rights, it is expected that they stay calm and comfortable while doing their job. Besides carrying people to travel from places to places, the land-transportation sector also has vital role as it contributes to the distribution of goods and services all over the nation. Therefore, the government, especially the Ministry of Transportation, Communication and Informatics should control the bus companies in South Sumatera related to their responsibility of providing appropriate compensation for the drivers in order to guarantee drivers' prosperity.

Finally, income disparity might not appear only to land-transportation sub sector. Thus, it is interesting to apply the Blinder-Oaxaca decomposition method in conducting other research on other sub sectors such as ship transportation and aviation.

\section{REFERENCES}

1. Arief, Sritua, 1993. Metodologi Penelitian Ekonomi. Jakarta: Universitas Indonesia.

2. Blinder, A. S., 1973. Wage Discrimination: Reduced Form and Structural

3. Estimates. The Journal of Human Resources. 8 (4). pp. 436-455.

4. Borjas, George J., 2000. Labor Economics, (Second edition). McGraw Hill-Irwin, Boston.

5. Gujarati, Damodar, 2004. Basic Econometrics, (Fourth Editio).McGraw Hill-Irwin, Boston.

6. Hasan, M. Iqbal, 2002. Pokok-pokok Materi Statistik 2, (Cetakan pertama).Sinar Grafika Offset, Jakarta.

7. Hwang, H., Mortensen, D.T. \& Reed, W.R., 1998. Hedonic wages and labor market search. Journal of Labor Economics, 16(4), 815-847.

8. Jogiyanto, 2005. Analisis dan Desain. Andi Offset, Yogyakarta.

9. Kaufman, Bruce E. dan Julie L. Hotchkiss, 2005. The Economics of Labor Markets.Georgia.Thompson, Atlanta.

10. Kementerian Perhubungan RI., 2013. Statistik Perhubungan 2012, (Buku 1). Jakarta.

11. Kuncoro, Mudrajad, 2003. Metode Riset Untuk Bisnis \& Ekonomi. Erlangga, Jakarta.

12. McConnel, Campbell R, Stanley L., Brue, David A. Macherson, 1999.Cotemporary Labor Economics. Mcgraw, Hill International Edition fifth Edition. San Fransisco.

13. Nugroho, dkk., 2012. Karakteristik Pengemudi dan Model Peluang Terjadinya Kecelakaan Bis AKAP. Jurnal Rekayasa Sipil/Volume 6, No. 1- 2012 ISSN 1978 - 5658. 
14. Nurlina, et al 2012. Ekonomi Ketenagakerjaan (Cetakan Kedua). Palembang: UnsriPress.

15. Nurlina, Tarmizi, 2014. Perilaku Pasar Tenaga Kerja, (Cetakan Pertama. Palembang: Unsri Press.

16. Oaxaca, Ronald.1973. Male-female Differentials in Urban Labor market. International Labor review, Volume 14.

17. Polachek, Solomon \& Siebert, Stanley. 1999. The Economics of Earnings. New

18. York; Press Syndicates of the University of Cambridge.

19. Rosen, Sherwin, 1983. The Equilibrium Approach to Labor Markets. National Burrau of Economic Research, Working Paper no. 1165

20. Rosen, Sherwin, 1986. The theory of equalizing differences. In O. Ashenfelter \& Layard, R. (Eds.). Handbook of Labor Economics, (Chapter 12). New York: Elsevier Science Publishers.

21. Sahab, Syukri, 1997. Teknik Manajemen Keselamatan dan Kesehatan Kerja.

22. Scasny and Jan Urban, 2006. Wage-Risk Relationship Test in Hedonic Wage Models in The Czech Republic. Charles University Environment Center.

23. Siebert, W.S. \& X. Wei, 1998. Compensation for Job Risk: The Case of Hongkong. Asian Economic Journal, 12, 171-181.

24. Sugiyono, 2013. Metode Penelitian Bisnis, (Cetakan ke-17). Alfabeta, Bandung.

25. Supranto, J., 2001. Statistik: Teori dan Aplikasi, (Edisi keenam). Erlangga, Jakarta.

26. Thaler, R.H. \& S. Rosen, 1976. The Value of Saving a Life: Evidence from the Labor Market. In Household Production and Comsumption. National Bureau of Economic Research, Inc.265-302.

27. Viscusi, W.K., 1980. Union, Labor Market Structure, and The Welfare Implications of the Quality of Work. Journal of Labor Research, 1, 175-192

28. Viscusi, 1993. The Value of Risks to Life and Health. Journal of Economic Literature, vol. XXX1.pp 1912-1946.

29. Viscusi. W.K. \& J.E. Aldy, 2003. The Value of a Statistical Life: A Critical Review of Market Estimates Throughout the World. Jounal of Risk and Uncertainty, 27, 5-76.

30. Wang, Haining, et.al., 2013. Compensating wage and Income Differentials for Occupational Risk: Evidence from migrant workers in China's Pearl River Delta. Monash University, Department of Economics ISSN 1441-5429. 